\title{
THE EFFECT OF ROOTSTOCKS ON THE GROWTH AND YIELDING OF SOUR CHERRY CV. 'LUTÓWKA'
}

\author{
Stanisław Wociór \\ University of Life Sciences in Lublin, Department of Seed Production and Nurseries, Leszczyńskiego 58, 20-068 Lublin, Poland \\ e-mail: stanislaw.wocior@.up.lublin.pl
}

Received: 7.01 .2008

\section{$\mathrm{S} \mathrm{u} \mathrm{m} \mathrm{m} \mathrm{a} \mathrm{r} \mathrm{y}$}

The strength of growth of ' $Ł u t o$ wka' trees was related to the soil quality and the rootstock. Measurements of the tree trunks and the crown size showed that on fertile soil the trees grafted on Mahaleb cherry grew worse, forming by $12 \%$ thinner trunks and by over $20 \%$ (significantly) smaller crowns as compared to Mazzard cherry trees. On poor sandy-loamy soil the crowns of trees grafted on Mahaleb were significantly, more than $40 \%$ bigger than those on Mazzard cherry. No significant differences in the yielding and productivity of trees grafted on Mahaleb and Mazzard cherry trees were found on grey brown podzolic soil. The experiment conducted on sandy-loamy soil pointed to significant differences in the yielding and productivity between 'Łutówka' trees grafted on the studied rootstocks. The trees grafted on Mahaleb cherry in both studied years were characterized by significantly greater productivity than on the other rootstocks. Significantly higher yields were gathered from the trees on Mahaleb cherry than on vegetative rootstocks, and by $70 \%$ higher than on Mazzard cherry. P-HL A rootstock is of little use in the planting of 'Łutówka', which grown poorly on light soils. Besides poor growth and yielding, in longer dry periods the studies found the appearance of chlorosis of magnesium on older leaves, and even wilting of the leaves.

Key words: sour cherry, rootstocks, soil, growth, yielding

\section{INTORODUCTION}

Poland is the biggest producer of sour cherry fruit in the European Union ( $\mathrm{M} \mathrm{a} \mathrm{k} \mathrm{o} \mathrm{s} \mathrm{z,} \mathrm{2006).}$

High yields and success in developing the fruit production were affected by the proper choice of cultivars, improvement of the production technology and intensification of production objects performed through increased density of planting ( Grz y b and Gronek, 1991; R o z para, 1995; Krawi e c, 2000; Mika et al. 2000; H o r o tk o, 2005).

Despite numerous papers estimating the production value of rootstocks ( $\mathrm{F} \mathrm{unk}, 1969 ; \mathrm{Grzyb}$ at al. 1987, Grzyb and Kolbusz, 1989, Ugolik et al. 1993; Selwa et al. 1994; Perry et al. 1996; Dencker and Toldam-Andersen, 2005; Nyeki and Szabo, 2005), there is still lack of information on the choice of rootstocks in different habitat conditions.

The purpose of the studies was to estimate the usefulness of rootstocks in different habitat conditions.

\section{MATERIALS AND METHODS}

The studies were conducted in the years 20042006 in two production orchards. The orchard belonging to Mr Trześniewski at Strączkowo in Samborzec commune was planted on grey-brown podzolic soil of II valuation class. The experiment in the orchard belonging to Mr Henryk Warsiński at Janów of Ożarów commune was set up on sandy loamy soil included in $\mathrm{IVb}$ valuation class (I class - the best soil, V class - the poorest soil).

The experimental material were the trees of 'Łutówka'.

The experiment was established in a scheme of random blocks. They included 2 or 5 combinations in 5 replications. The replications were the plots where 3 trees grew on each. The experimental combinations at Strączków were ' $Ł u t o ́ w k a '$ trees grafted on Mahaleb cherry and Mazzard cherry planted in 2001. On the other hand, the trees of 'Eutówka' grafted on the seedlings of Mahaleb and Mazzard cherry and on vegetative rootstocks Colt and P-HL A and F 12/1 were planted in Janów in 2001.

In both experiments the trunk diameter was measured at the height of $30 \mathrm{~cm}$, and the width and height of the tree crowns were measured. The yield from each tree was weighed. The area of the cross-section of the trunks, the cubic content of the crowns and the productivity of trees and crowns were calculated on the basis of these studies.

Results of studies were statistically analyzed using variance analysis and Tukey's confidence intervals. 


\section{RESULTS AND DISCUSSION}

In the case of the orchard on grey-brown podzolic soil ' $Ł u t o ́ w k a '$ trees grafted on Mazzard cherry formed thicker trunks and bigger crowns than on Ma- haleb cherry. Significant differences between rootstocks were shown only for the size of the crown. Similar results were obtained by Tylus et al. (1986) and S e lw a et al. (1994).

Table 1

Influence of rootstocks and kind of soil on growth of the trees of sour cherry cultivar 'Łutówka' in 2004-2006.

\begin{tabular}{|c|c|c|c|c|c|c|c|}
\hline \multirow{3}{*}{ Rootstocks } & \multicolumn{7}{|c|}{ Trunk cross section area in $\mathrm{cm}^{2}$} \\
\hline & \multicolumn{3}{|c|}{ Sandy loamy soil } & \multicolumn{4}{|c|}{ Grey-brown podzolie soil } \\
\hline & 2004 & 2005 & $\begin{array}{c}\text { Percent to } \\
\text { Mazzard }\end{array}$ & 2004 & 2005 & 2006 & $\begin{array}{l}\text { Percent } \\
\text { to Mazzard }\end{array}$ \\
\hline 1. Mazzard & $29.4 \mathrm{ab}$ & $39.7 \mathrm{ab}$ & 100 & 29.0 & 43.3 & 54.6 & 100 \\
\hline 2. Mahaleb & $29.3 \mathrm{ab}$ & $36.4 \mathrm{~b}$ & 92 & 27.9 & 37.4 & 48.3 & 88 \\
\hline 3. $\mathrm{PHL}-\mathrm{A}$ & $17.5 \mathrm{c}$ & $27.3 \mathrm{c}$ & 69 & - & - & - & - \\
\hline 4. F $12 / 1$ & $25.2 \mathrm{~b}$ & $40.2 \mathrm{ab}$ & 101 & - & - & - & - \\
\hline 5. Colt & $32.7 \mathrm{a}$ & $43.1 \mathrm{a}$ & 109 & - & - & - & - \\
\hline LSD $p=0.05$ & 7.2 & 6.5 & - & ns & ns & ns & - \\
\hline
\end{tabular}

Measurements of the trees growing on sandy loamy soil did not show any significant differences in the trunk thickness between the trees grafted on the above mentioned two rootstocks, but the tree crowns on Mahaleb cherry were significantly, by $41 \%$ bigger than on Mazzard cherry. In the discussed habitat conditions the trees grafted on P-HL A grew significantly worse.
The trees grafted on Colt rootstock grew more strongly than on the seedlings of Mazzard cherry. 'Eutówka' on F 12/1 vegetative rootstock did not significantly differ with the trunk thickness and the crown volume from the trees on Mazzard cherry. This confirms the observations made by R o zpara (1995).

Table 2

Influence of rootstocks on size of crown of sour cherry cultivar ' $Ł u$ tówka' in 2004-2006.

\begin{tabular}{|lccccc|}
\hline & \multicolumn{5}{c|}{ Volume of the crowns in $\mathrm{m}^{3}$} \\
\cline { 2 - 6 } & \multicolumn{2}{c}{ Sandy loamy soil } & \multicolumn{3}{c|}{ Grey-brown podzolie soil } \\
\cline { 2 - 6 } & 2005 & $\begin{array}{c}\text { Percent } \\
\text { to Mazzard }\end{array}$ & 2004 & 2005 & 2006 \\
\hline 1. Mazzard & $2.51 \mathrm{~b}$ & 100 & $1.4 \mathrm{a}$ & $2.2 \mathrm{a}$ & $3.5 \mathrm{a}$ \\
2. Mahaleb & $3.54 \mathrm{a}$ & 141 & $1.1 \mathrm{~b}$ & $1.6 \mathrm{~b}$ & $2.8 \mathrm{~b}$ \\
3. PHL A & $1.23 \mathrm{c}$ & 49 & - & - & - \\
4. F 12/1 & $1.97 \mathrm{bc}$ & 78 & - & - & - \\
5. Colt & $2.86 \mathrm{ab}$ & 114 & - & 0.3 & 0.5 \\
\hline LSD p=0.05 & 0.9 & - & 0.2 & - \\
\hline
\end{tabular}

The accessible literature does not provide any data on the effect of P-HL rootstock on the growth of sour cherry trees. Perry et al. (1996), conducting studies on sandy-loamy soil, pointed to a much stronger growth of 'Montmorency' cv. cherry on Colt rootstock as compared to Mazzard and Mahaleb cherry trees. 
Table 3

Influence of rootstocks on yielding of sour cherry cultivar ' $Ł u$ tówka'.

\begin{tabular}{|c|c|c|c|c|c|c|c|c|c|}
\hline \multirow{3}{*}{ Rootstocks } & \multicolumn{9}{|c|}{ Yield from tree in $\mathrm{kg}$} \\
\hline & \multicolumn{4}{|c|}{ Sandy loamy soil } & \multicolumn{5}{|c|}{ Grey-brown podzolie soil } \\
\hline & 2004 & 2005 & $\bar{x}$ & $\begin{array}{c}\% \\
\text { to Mazzard }\end{array}$ & 2004 & 2005 & 2006 & $\bar{x}$ & $\begin{array}{c}\% \\
\text { to Mazzard }\end{array}$ \\
\hline 1. Mazzard & $10.6 \mathrm{~b}$ & $3.7 \mathrm{ab}$ & 7.1 & 100 & \multirow{5}{*}{$\begin{array}{l}3.0 \\
3.0\end{array}$} & \multirow{5}{*}{$\begin{array}{l}7.7 \\
7.1\end{array}$} & \multirow{5}{*}{$\begin{array}{l}15.0 \\
12.8\end{array}$} & \multirow{5}{*}{8.6} & \multirow{5}{*}{100} \\
\hline 2. Mahaleb & $18.2 \mathrm{a}$ & $6.0 \mathrm{a}$ & 12.1 & 170 & & & & & \\
\hline 3. PHL A & $5.3 \mathrm{c}$ & $1.7 \mathrm{~b}$ & 3.5 & 49 & & & & & \\
\hline 4. F $12 / 1$ & $8.7 \mathrm{bc}$ & $2.3 \mathrm{~b}$ & 5.5 & 78 & & & & & \\
\hline 5. Colt & $9.1 \mathrm{bc}$ & $3.1 \mathrm{~b}$ & 6.1 & 86 & & & & & \\
\hline LSD $p=0.05$ & 4.8 & 2.8 & - & - & ns & ns & ns & - & - \\
\hline
\end{tabular}

Trees on Mazzard cherry on fertile soil gave a yield on average by $10 \%$ higher than on Mahaleb. No significant differences between the rootstocks were shown in particular years. Fruiting of the trees grafted on Mahaleb cherry planted on poorer soil was by about $70 \%$ higher than on Mazzard cherry. In 2004 the differences between these rootstocks were significant. 'Łutówka' trees grafted on vegetative rootstocks yielded worse than on the seedlings. The differences between the yielding of trees on Mahaleb cherry and the three studied vegetative rootstocks proved to be significant.

Different views were found in the literature on the subject about the effect of Mahaleb and Mazzard cherry trees on the yielding of sour cherries. U g o li k et al. (1993) and P e r ry et al. (1996) found out, like in the present studies conducted on poor soil, much better yielding of trees on Mahaleb as compared to Mazzard cherry. On the other hand, Tylus et al. (1996);
Grzyb and Gronek (1991); S e lwa et al. (1994) and Grzyb et al. (1987) obtained much better yields on Mazzard cherry than on Mahaleb. A similar tendency was observed in the present studies conducted in the orchard on fertile soil.

Rozpara (1995) reports a differentiated scheme of yields in the experiments comparing the fruiting of sour cherry on F 12/1 rootstock and on the seedlings of Mazzard cherry in different habitat conditions. In Albigowa and Sinołęka the trees of ' $Ł u$ úwka' yielded a little better on the seedlings, like in the present experiment, while in Przybroda slightly higher yields were obtained on F 12/1.

In the case of trees grafted on P-HL A in summer the studies observed considerable intensification of the symptoms of chlorosis of magnesium leading to premature falling of the leaves from the lower part of oneyear-old shoots.

Table 4

Influence of rootstocks on efficiency of sour cherry cultivar ' $L u$ úwka'.

\begin{tabular}{|c|c|c|c|c|c|}
\hline \multirow{3}{*}{ Rootstocks } & \multicolumn{5}{|c|}{ Efficiency of trees in $\mathrm{kg} \times \mathrm{cm}^{2}$} \\
\hline & \multicolumn{2}{|c|}{ Sandy loamy soil } & \multicolumn{3}{|c|}{ Grey-brown podzolie soil } \\
\hline & 2004 & 2005 & 2004 & 2005 & 2006 \\
\hline 1. Mazzard & $0.36 \mathrm{~b}$ & $0.09 \mathrm{~b}$ & 0.01 & 0.18 & 0.27 \\
\hline 2. Mahaleb & $0.62 \mathrm{a}$ & $0.16 \mathrm{a}$ & 0.01 & 0.19 & 0.26 \\
\hline 3. PHL A & $0.30 \mathrm{~b}$ & $0.06 \mathrm{~b}$ & & & \\
\hline 4. F $12 / 1$ & $0.34 \mathrm{~b}$ & $0.06 \mathrm{~b}$ & & & \\
\hline 5. Colt & $0.28 \mathrm{~b}$ & $0.07 \mathrm{~b}$ & & & \\
\hline LSD $p=0,05$ & 0.12 & 0.04 & ns & ns & $\mathrm{ns}$ \\
\hline
\end{tabular}

No significant differences in the productivity of trees grafted on the seedlings of Mahaleb and Mazzard cherry trees were observed in the orchard growing on fertile soil. On the other hand, significantly greater pro- ductivity of the trees grafted on Mahaleb was observed as compared to the other rootstocks.

The present studies will be continued with the aim of studying the planting at full fruiting. 


\section{CONCLUSIONS}

1. The strength of growth of 'Łutówka' trees was related to the soil quality and the rootstock. Measurements of the tree trunks and the crown size showed that on fertile soil the trees grafted on Mahaleb cherry grew worse, forming by $12 \%$ thinner trunks and by over $20 \%$ (significantly) smaller crowns as compared to Mazzard cherry trees. On poor sandy-loamy soil the crowns of trees grafted on Mahaleb were significantly, more than $40 \%$ bigger than those on Mazzard cherry.

2. Trees of P-HL A on sandy-loamy soil grew significantly worse as compared to the trees on the seedlings and Colt rootstock.

3. No significant differences in the yielding and productivity of trees grafted on Mahaleb and Mazzard cherry trees were found on grey-brown podzolic soil.

4. The experiment conducted on sandy-loamy soil pointed to significant differences in the yielding and productivity between 'Lutówka' trees grafted on the studied rootstocks. The trees grafted on Mahaleb cherry in both studied years were characterized by significantly greater productivity than on the other rootstocks. Significantly higher yields were gathered from the trees on mahaleb cherry than on vegetative rootstocks, and by $70 \%$ higher than on Mazzard cherry.

5. P-HL A rootstock is of little use in the planting of 'Łutówka' cv., which grown poorly on light soils. Besides poor growth and yielding, in longer dry periods the studies found the appearance of chlorosis of magnesium on older leaves, and even wilting of the leaves.

\section{REFERENCES}

Dencker I., Toldam-Andersen T. B.2005. Effects of rootstock, winter temperature and potassium fertilization on yield components of young sour cherries. Acta Hort. 667: 409-414.

Funk T. 1969. Das obstbauliche Verhalten der Schatenmorellen auf einigen Sorteureinen Mahalebunterlagen im Vergleich zu Prunus avium HZ 170 und Vogelkirschenmischung bis zum 10 standjahr. Arch. Gartenbau, 17: 101-115.

Grzyb Z.S., Czynczyk A., Jackiewicz A. 1987. The influence of different rootstocks and height of grafing on the vigor and yield of three sour cherry cvs. Prace ISiK, Seria A, 27: 11-18.

Grzyb Z. S., Kolbusz S.M. 1989. Influence of selected rootstocks on health status, vigor and bearing of three sour cherry cultivars. Fruit Sc. Rep. 16 (4): 215-224.

Grzyb Z. S., Gronek M. 1991. Growth and fruiting of sour cherry on different rootstocks in Pomorania region. Prace Inst. Sadow. Kwiac. Skiern. ser. A, 30: 55-60.

Horotko K. 2005. Developments in high density cherry production in Hungary. Acta Hort. 667: 279-283.
Krawiec P. 2000. Yielding of sour cherry trees planted in different spaces during full leaving period. Nowocz. Uprawa Drzew Pest., XX Międz. Sem. Sad. Limanowa: 127-137.

Makosz E. 2007. Fruit production of the great important species in future. XXVII Międzyn. Sem. Sad. Limanowa: 17-34.

Mika A., Wawrzyńczak P., Buller Z., Krawiec A., Salamon Z. 2000. The intensive production of sour cherry trees for mechanically harvesting. Nowocz. Uprawa Drzew Pest., XX Międz. Sem. Sad. Limanowa: 57-68.

Nyeki J., Szabo Z., Szabo P.2005. Fertility of sour cherry varieties selected in Hungary. Acta Hort. 667: 403-405.

Perry R. L., Runkel J. L., Longstroth M. A. 1996. The effects of rootstock on the preformance of 'Hedelfinger' and 'Montmorency' cherry in Michigan, USA. Acta Hort. 410: 257-268.

Rozpara E. 1995. Cultivars useing for sour cherry and sweet cherry orchard on the basic of experiment which was done in Research Institute of Pomology and Floriculture. Nowoczesna technologia uprawy wiśni i czereśni. Prace Inst. Sadow. Kwiac. Skiern.: 7-14.

Selwa J., Wociór S., Lipecki J., Doraczyński G., Leśniak A. 1994. Influence of rootstocks on growth and yielding of sour cherry cv. 'Łutówka' and 'North Star'. Ann. Univ. Mariae Curie-Skłodowska, Lublin, sect. EEE, II, 16: 117-123.

Tylus K., Grzyb Z. S., Czynczyk A. 1986. Growth and yielding of sour cherry trees cv. 'Łutówka' on different rootstocks. Prace Inst. Sadow. Kwiac. Skiern. Seria A, 26: 65-73.

Ugolik M., Hołubowicz T., Kantorowicz-Bąk M. 1993. Influence of rootstocks on growth, yielding and mineral contents in leaves of sour cherry cv. 'North Star', 'Kelleris 16' and 'Łutówka'. Inf. o badaniach Kat. Sadownictwa AR Poznań t. III: 43-47.

\section{Wpływ podkładek na wzrost i plonowanie wiśni odmiany 'Lutówka'}

\section{Streszczenie}

Siła wzrostu drzew Łutówki zależała od jakości gleby i podkładki. Pomiary grubości pni i wielkości koron wykazały, że na żyznej glebie drzewa okulizowane na antypce rosły słabiej tworząc o $12 \%$ cieńsze pnie i o ponad $20 \%$ (istotnie) mniejsze korony niż na czereśni ptasiej. Na słabej glebie piaszczysto-gliniastej korony drzew okulizowanych na antypce były istotnie, o ponad $40 \%$ większe niż na czereśni ptasiej. $\mathrm{Na}$ glebie płowej nie stwierdzono istotnych różnic plonowania i produktywności drzew okulizowanych na czereśni ptasiej i antypce. $\mathrm{W}$ doświadczeniu wykonanym na glebie piaszczysto-gliniastej wykazano istotne różnice plonowania i produktywności między drzewami Łutówki, okulizowanymi na badanych podkładkach. Drzewa okulizowane na antypce w obydwu 
latach badań charakteryzowały się istotnie wyższą produktywnością niż na pozostałych podkładkach. $\mathrm{Z}$ drzew na antypce zebrano istotnie wyższe plony niż na podkładkach wegetatywnych a także o $70 \%$ wyższe niż na czereśni ptasiej. Podkładka P-HL A jest mało przydatna do nasadzeń słaborosnącej odmiany Łutówka na glebach lekkich. Oprócz słabego wzrostu i plonowania drzew stwierdzono pojawianie się w dłuższych okresach suszy chlorozy magnezowej na starszych liściach a nawet więdnięcia liści. 
